\title{
Stochastic Pattern of Health Care Spending: Evidence from Nonlinear Panel Data Analysis
}

\author{
Nermin Yasar* \\ Department of Foreign Trade, Cankaya University, Ankara/Turkey.

\begin{abstract}
This paper analyses the stochastic pattern of health care spending for 188 countries around the world which are categorized into four groups based on the World Bank income categories. The main motivation of this article is to evaluate whether the stochastic features of total health care expenditure varies if decomposed into private and public health care consumption. To achieve this goal, in addition to conventional empirical methods, latterly developed panel stationarity approaches are employed for both linear and nonlinear regression processes. Our results demonstrate that allowing for cross-section dependency between series and nonlinearity in the estimation process may lead to more often rejection of the null hypothesis of unit root for all series in panel data set.
\end{abstract}

Keywords: Health Care Consumption, Panel Unit Root Test, Panel Cross Section Dependence, Nonlinearity, Heterogeneous Panel Unit Root.

JEL Classification: C10, C23, I10.

\section{INTRODUCTION}

The amount of money spent on total health care and its various elements known basically as health care expenditure is one of the main subjects for the considerable number of empirical researches in health economy literature in recent decades. As McCanne (2010) points out, a successful health care system essentially aims to keep society healthy, treat the sick, and protect people from high medical bills that may cause economic tightness. Since a healthier population has a propensity for higher labour productivity and stimulate investment in physical capital, health care expenditures have crucial effects on economic welfare and growth making health policy implementations very critical for all governments (Bloom and Canning, 2000). Analysing the health care expenditure behaviour as well as its consequences on national income is fundamental for the economic growth and development process regardless of the income group that country belongs to.

Although there are numerous studies investigating health care expenditure by various country groups, periods and applied methods, there is no consensus on the particular empirical evidence as well as feasible health policy implication obtained as a result of these researches. The first study in this sphere is Groosman (1972) which claims that healthcare may be considered as a durable capital stimulating output growth process. The other consequential study is Newhouse (1977) insists that income elasticity of demand for health products may be more than one for developed economies, which through the technical definition ultimately implies that health is not necessity consumption. Nevertheless, Hitiris and Pos-

*Address correspondence to this author at Department of Foreign Trade, Cankaya University, Ankara/Turkey; E-mail: nerminyasar@cankaya.edu.tr nett (1992) reinvestigates the findings of some earlier studies and also expresses suspicions about the luxury consumption of health care products. Still, Gerdtham et al. (1992), Okunade and Karakus (2001), Musgrove et al. (2002), Murthy and Okunade (2009), Lee et al. (2019) find out that health care goods and services are luxury consumption and this sector should be shaped by the market mechanism under competitive conditions like other industries in the economy. However, Jewell et al. (2003), Dreger and Reimers (2005), Mohamed (2009), Ke et al. (2011), Pattnayak et al. (2016) Kouassi et al. (2018), Rana et al. (2020) argue that health care represents a necessity consumption and that is why the government should use more interventionist policy instruments to protect consumers and to ensure the integrity of the health care market. So, we may conclude that depending on whether an increase in health care consumption is smaller than the rising in total income in the economy, health care policy implications adopted by the government may differ.

On the other side, since early studies in this field employ more simple empirical methods, possible non-stationarities of the concerned series may be ignored in some of these studies causing statistically questionable results. According to Phillips (1986), the results obtained from the conventional time-series estimation process may be spurious if concerned series are non-integrated or include a unit root. Moreover, Okunade and Karakus (2001) states that based on whether observed time series follow a unit root process or not, indicators from the estimated model may contain biased information resulting in misguided health care policy inferences for governments. In this context, several studies as Hansen and King (1996), Gerdtham and Lothgren (2002), Baltagi et al. (2010), Mehrara et al. (2012), Rodríguez and Valdés (2019), Kouassi et al. (2018), Lee et al. (2019), Rana et al. (2020) employ newly developed applied techniques to inves- 
tigate the correlation among health care spending and GDP considering possible non-stationarities in the estimation procedure of time series or panel data and find out that both of these variables contain stochastic trend. However, McCoskey and Selden (1998), Jewell et al. (2003), Carrion-iSilvestre (2005), Lago-Peñas (2013), obtain strong evidence of stationarity for both healthcare spending and GDP series using similar empirical methods.

As it can be inferred from the studies above, there is no single evidence on the stochastic pattern of the health care expenditures series that may cause some serious problems for health care economists and policymakers from various aspects. For instance, following Hendry and Juselius (2000), parameters concerned to the level of any non-stationary parameters will inherit this feature and transfer it to other variables. In other words, if health care expenditure series follow a process with a stochastic trend or a unit root, then it may be diffused to other economic indicators. In this case, as Hasanov and Telatar (2011) states, to evaluate the appropriate empirical estimation methodology to achieve statistically meaningful results, firstly the unit root analysis should be done carefully. Moreover, if health care spending series are non-stationary, then shocks on health care consumption may have persistent effects on these series. However, if health care expenditure does not follow a stochastic trend, then fluctuations may have short-term or temporal effects and health care spending may recur to its initial equilibrium level as time progresses encouraging policymakers to take fewer interventionist actions in the healthcare market process.

Even though a stochastic pattern of health care spending series is one of the well-studied subjects, as far as we know, there are no known researches that consider eventual nonlinearities in the data generating process of these series. Following Roberts (1999), health care variables may contain non-linear properties and although it is the subject that requires specific attention, it has been ignored by researchers in previous studies. Thence, the main motivation of this study is to revise empirical evidence of unit root for total, public and private health care spending series generated both linearly and non-linearly as well as to test whether the stochastic features of total health care expenditure vary if it is disaggregated into private and public health care consumption.

The next section concisely discusses the applied estimation methodology implemented in this research. The third section provides empirical findings and the last section procures a concluding notion.

\section{ANALYTICAL METHODS}

\section{Panel Linear Unit Root}

Augmented Dickey-Fuller (Dickey and Fuller, 1979) technique illustrated as follows, is broadly employed in empirical literature to analyse the stochastic features of observed variables.

$\Delta y_{i, t}=\alpha_{i}+\beta_{i} y_{i, t-1} \sum_{j=1}^{k} y_{i} \Delta y_{t-j}+u_{i t}$ where $y_{i, t}$ indicates health care expenditure and $\Delta$ is the difference operator. $\alpha_{i}, \beta_{i}$ and $y_{i}$ are coefficients considered to be estimated and $u_{i t}$ is adopted as white noise (Hasanov and Telatar, 2011). The null hypothesis of non-stationarity is $\mathrm{H} 0: \beta_{i}=0 \forall i$, where opposite hypothesis $\mathrm{H} 1$ implies that, $\beta_{i} \neq 0 \forall i$ is based on;

$t_{N L}=\frac{\widehat{\beta}}{\text { s.e. }(\widehat{\beta})}$

Here, $\hat{\beta}$ is the estimation of $\beta$ and s.e. $(\beta)$ is the multiple standard errors. Depending on the existence of correlation ( $\rho i)$ across the residuals of the units in the panel data, that is whether cross-sectional dependency exists between the units or not, mainly two types of stationarity tests known as a first and second generation are employed in the empirical researchers. On the other hand, depending on whether the individuals of the panel are characterized by different dynamics or not, the first-generation panel stationarity approaches that predict cross-sectional independence among the panel can be categorized as homogeneous or heterogeneous in the panel data estimation process. The first type panel unit root analyses applied in this paper such as Hadri (2000), Breitung (2001) and Levin et al. (2002) tests require homogeneity across the series, suggesting that $\rho i$ is self-same for all crosssectional data $(\rho \mathrm{i}=\rho$ ), whereas Maddala and $\mathrm{Wu}(1999)$, Choi (2001), Im et al. (2003) analyses take into consideration the heterogeneity in the dynamics of autoregressive parameters, releasing Levin et al. (2002)'s other hypothesis assumption that $\rho i$ is the same for all series.

\section{Panel Non-Linear Unit Root}

According to Taylor et al. (2001), temporal aggregation and nonlinearity may significantly impair the findings of classical stationarity tests. To eliminate this difficulty, we employ Kapetanios et al. (2003) test procedure constructed on an exponential smooth transition (ESTAR) regression system which allows for nonlinearities in the regression process as well as provides more powerful results than the traditional ADF test. It suggests a simple technique allowing to distinguish whether the data regression process is a nonlinear but globally stationary system versus the existence of non- stationarity.

Assume that, $y_{t}$ is the series under consideration and follow a simple ESTAR model of order 1:

$y_{t}=\beta y_{t-1}+\gamma y_{t-1}\left[1-\exp \left(-\theta y_{t-d}^{2}\right)\right\rfloor+u_{i t}$

which can be expressed as below after rearranging

$\Delta y_{t}=\phi y_{t-1}+\gamma y_{t-1}\left\lfloor 1-\exp \left(-\theta y_{t-d}^{2}\right)\right\rfloor+u_{i t}$

and where $\phi=\beta-1$ and $F\left(\theta, y_{t-d}\right)=\left\lfloor 1-\exp \left(-\theta y_{t-d}^{2}\right)\right\rfloor$

Global stationarity of $y_{t}$ is tested under the null hypothesis $\mathrm{H}_{0}: \theta=0$, where alternative hypothesis $\mathrm{H} 1: \theta>0$. Since $\gamma$ is 
not specified under the null, examining $\mathrm{H} 0$ in the absence of deviation is not practical. To solve this difficulty Kapetanios et al. (2003) proposes the technique recommended by Luukkonen et al. (1998) and substitute the transition process $F\left(\theta, y_{t-d}\right)$ by its appropriate Taylor approximation around $\theta$ $=0$ and maintain $\mathrm{t}$-type test statistic. The auxiliary regression model acquired by implementing the Taylor approximation is as follows;

$\Delta y_{i, t}=\delta y_{t-d}^{3}+e_{t}$

where $e_{t}$ contains fluctuations and error term remaining from Taylor approximation. The t-test value here can be obtained as below:

$t N L=\frac{\widehat{\delta}}{\text { s.e. }(\widehat{\delta})}$

Here, $\hat{\delta}$ remarks the ordinary least squares estimation of $\delta$ and s.e. $(\hat{\delta})$ denotes the standard deviation of $\hat{\delta}$. In this case, an augmented regression model can be impressed as below:

$\Delta y_{i, t}=\sum_{j=1}^{p} \rho \Delta y_{t-j}+\delta y_{t-d}^{3}+e_{t}$

\section{Panel Cross-Sectional Dependency}

Without considering the existence of cross-section dependence in the panel regression process one may significantly affect the results obtained from this model (Breusch and Pagan, 1980; Pesaran, 2004). Cross-section independence across the parameters of the panel implies that all crosssectional units of this data set will be affected at a similar level from any shocks on the unit. In this case, if there are any macroeconomic shocks in any countries in the panel then other countries will not be affected by these fluctuations. Following Phillips and Sul (2003), first-generation panel stationarity analysis may be biased in the existence of crosssection dependency among the panel data. To overcome this issue, we employ the test statistic denoted below.

$$
C D=\sqrt{\frac{2 T}{N(N-1)}}\left(\sum_{i=1}^{N-1} \sum_{J=i+1 \hat{\rho} i, J}^{N}\right) d N(0,1)
$$

Here, $\hat{\rho} i, j$ is the estimated correlation parameter of the residuals of the ADF model (1). Within the framework of H0 which implies cross-sectional independence with $\mathrm{T} \rightarrow \infty$ and $\mathrm{N} \rightarrow \infty$, CD test value follows asymptotic distribution as standard normal (Pesaran, 2004).

\section{Panel Linear Unit Root with Cross-Sectional Dependency}

Following the conventional augmented Dickey-Fuller regression, Pesaran (2007) suggests a new test procedure that is expanded by the average of cross-section lag levels and first differences of the considered variables. CADF test statistics should be inferred from below indicated OLS regression model;

$$
\begin{aligned}
& \Delta y_{i, t}=\alpha_{i}+\beta_{i} y_{i, t-1}+y_{i} \bar{y}_{i, t-1}+ \\
& \sum_{j=0}^{p} \eta_{i j} \Delta \bar{y}_{t-j}+\sum_{j=1}^{p} \phi_{i j} y_{i, t-1}+e_{i, t}
\end{aligned}
$$

Here, $\bar{y}_{t}$ is the cross-section average at the period t. The test value for the null hypothesis of non-stationarity, against the opposite one, is derived as indicated below:

$$
\operatorname{CIPS}(N, T)=t_{N, T}=N^{-1} \sum_{i=1}^{N} t_{i}(N, T)
$$

Here, $t_{i}(N, T)$ is the t-ratio of the $\beta_{i}$ from equation (6).

\section{Panel Non-Linear Unit Root with Cross-Sectional De- pendency}

Following Kim and Kim (2018) next, we used Cerrato et.al. (2011) nonlinear panel stationarity analysis. This test procedure is an augmented version of the nonlinear ESTAR stationarity regression process asserted by Kapetanios et al. (2003) which takes into consideration a cross-section dependence between the series, combining it with the test procedure proposed by Pesaran (2007). Cerrato et.al. (2011) suggests a nonlinear heterogeneous panel stationarity test procedure examining the null hypothesis of non-stationarity, where the opposite one implies that the variables generated by globally stationary ESTAR procedures and the remaining parts of the series obtained by non-stationary processes. This technique accommodates both nonlinearity and crosssectional dependence and predicts the following estimation process;

$$
\begin{aligned}
& \Delta y_{i, t}=\alpha_{i}+\beta_{i 0} y_{i, t}^{3}+y_{i, 0} \bar{y}_{i, t-1}^{3}+ \\
& \sum_{j=1}^{p}\left(\eta_{i, j} \Delta y_{i, t-j}+y_{i, j} \bar{y}_{i, t-1}^{3}\right)+e_{i t}
\end{aligned}
$$

where $\bar{y}_{t}$ is cross-section average at time t. The null hypothesis of stationarity, against the opposite hypothesis, is tested via Im et al. (2003) type test value which is obtained as below:

$t_{N, T}=N^{-1} \sum_{i=1}^{N} t_{i}(N, T)$

Here, $t_{i}(N, T)$ is the t-ratio of $\beta_{i 0}$ from equation (7).

\section{EMPIRICAL RESULTS}

This study analyses the stochastic characteristics of the health care spending series for 188 economies over the period 1995-2014 achieved from the World Bank's World Development Indicators. Private health expenditure, public health expenditure and total health expenditure as \% of GDP are investigated for each country group.

Total health consumption is composed of whole public and private expenditures for whole health care goods and services, whereas public health care spending is funded by social security endowment, as well as different types of assessment to different spheres of government, and exterior agencies involving both grants and loans. However, private health care spending involves non-public premiums paid for insurance and prepaid schemes, obligated enterprise health 
spending and healthcare spending through non-profit health services (Poullier et al., 2002).

Firstly, we analyse stationarity properties of the health care expenditure, ignoring possible non-linearities in the observed series by implementing conventional panel unit root approaches proposed by Maddala and Wu (1999), Choi (2001) and Levin and et al. (2002).

Table 1. Panel Unit Root Test.

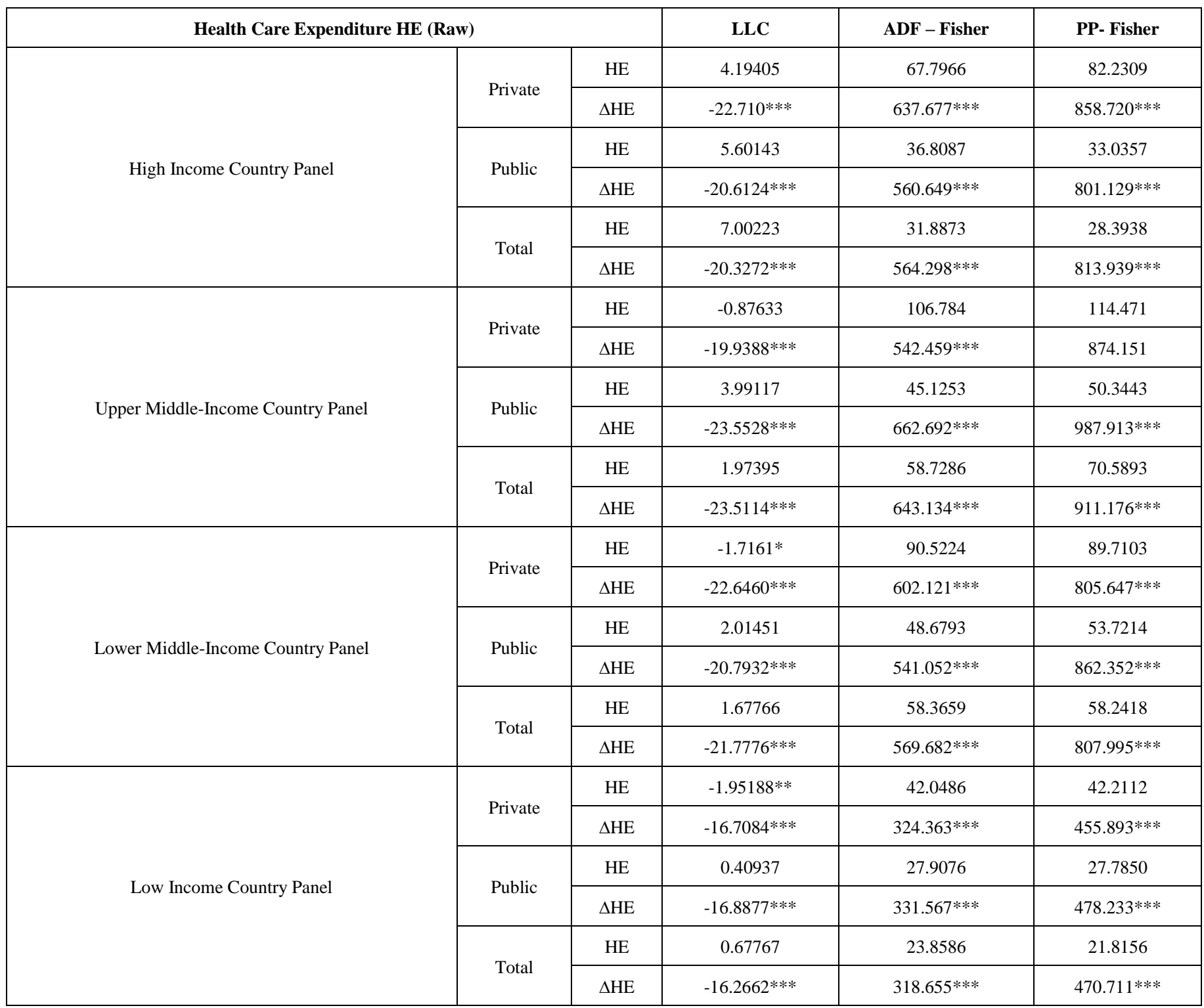

Note: *, **, and *** remarks rejection of the $\mathrm{H}_{0}$ at $\% 10, \% 5,1 \%$ significance level, respectively. Here, HE demonstrates healthcare expenditure series in level and $\triangle \mathrm{HE}$ symbolises the first differences of the series.

Based on the findings in Table 1, it can be concluded that total health consumption series are non-stationary in the level for all country groups. However, disaggregating these series as public and private does not demonstrate strong evidence of non-stationarity providing mixed results. In this case, results obtained from health care expenditure series may lead to specious inferences.

As Getzen and Poullier (1992) states health care spending is actually based on both permanent and transitory items of income as well as determined by several aspects which include organizational dynamics, technological developments and expectations. Moreover, according to Roberts (1999) electoral cycles and macroeconomic fluctuations also may have a remarkable impact on the public expenditure on health care. These facts cause health care spending series to be dynamic, which in its own turn may lead to the questioning of the linearly obtained test results. So, investigating stochastic features of health care expenditure by allowing for nonlinearities in the estimation process may prove beneficial. For this purpose, the LM-type test proposed by Luukkonen et. al. (1988) and Granger and Terasvirta (1993) is employed in this analysis. 
Table 2. Panel Linearity Test.

\begin{tabular}{|c|c|c|c|c|}
\hline & $\begin{array}{c}\text { Health Care } \\
\text { Expenditure } \\
\text { HE }\end{array}$ & $d=1$ & $\mathrm{~d}=\mathbf{2}$ & $\mathbf{d}=\mathbf{3}$ \\
\hline \multirow{3}{*}{$\begin{array}{c}\text { High } \\
\text { Income } \\
\text { Country } \\
\text { Panel }\end{array}$} & Private & $67.66993 * * *$ & 0.518026 & 1.509915 \\
\hline & Public & -0.719799 & 1.632995 & $2.304058^{* *}$ \\
\hline & Total & -0.916257 & 0.681261 & 1.461784 \\
\hline \multirow{3}{*}{$\begin{array}{c}\text { Upper } \\
\text { Middle- } \\
\text { Income } \\
\text { Country } \\
\text { Panel }\end{array}$} & Private & $-2.178852 * *$ & $-2.5199 *$ & $-2.0896 * *$ \\
\hline & Public & $\begin{array}{c}- \\
11.07258 * * *\end{array}$ & -0.374220 & 0.170351 \\
\hline & Total & $\begin{array}{c}- \\
9.117303^{* * *}\end{array}$ & 0.693293 & 0.987588 \\
\hline \multirow{3}{*}{$\begin{array}{c}\text { Lower } \\
\text { Middle- } \\
\text { Income } \\
\text { Country } \\
\text { Panel }\end{array}$} & Private & $-2.093191 * *$ & $\begin{array}{c}- \\
2.093191 * * * \\
\end{array}$ & -0.650211 \\
\hline & Public & -0.136506 & 0.649801 & -0.423113 \\
\hline & Total & -0.458984 & 0.055016 & -0.582896 \\
\hline \multirow{3}{*}{$\begin{array}{c}\text { Low } \\
\text { Income } \\
\text { Country } \\
\text { Panel }\end{array}$} & Private & $-2.308535^{* *}$ & -0.185913 & 0.447127 \\
\hline & Public & 0.326674 & 1.094084 & $2.162798 * *$ \\
\hline & Total & -1.510829 & 0.991956 & 0.884460 \\
\hline
\end{tabular}

Note: $*, * *$, and $* * *$ remarks rejection of $\mathrm{H} 0$ at $\% 10, \% 5,1 \%$ significance level, respectively.

From the results in the table above, the null hypothesis of linearity may be ignored only for private health care spending in each country group. The possible cause for this is the uncertainty and competitive conditions which are deeply rooted in the private health sector. For instance, consumption of private health care goods and services may decrease drastically in periods of intense economic uncertainty leading to prominent fluctuations in private health care spending series. On the other side, according to our results, this is not the case for the public sector. Limited competitive conditions along with the policy makers' motivation for getting the majority of votes in upcoming elections, may stabilize healthcare spending in the public sector inducing these series to follow a linear pattern.

Table 3. Panel Nonlinear Unit Root Test.

\begin{tabular}{|c|c|c|c|c|}
\hline & $\begin{array}{c}\text { Health Care } \\
\text { Expenditure } \\
\text { HE }\end{array}$ & Raw & Demeaned & De-trended \\
\hline \multirow{3}{*}{$\begin{array}{c}\text { High } \\
\text { Income } \\
\text { Country } \\
\text { Panel }\end{array}$} & Private & $\begin{array}{c}- \\
3.336088 * * *\end{array}$ & -2.515621 & -2.745147 \\
\hline & Public & -1.669191 & $-3.139765^{* *}$ & $-3.438078^{* *}$ \\
\hline & Total & -1.272411 & -0.318787 & -0.655018 \\
\hline \multirow{2}{*}{$\begin{array}{l}\text { Upper } \\
\text { Middle- } \\
\text { Income } \\
\text { Country }\end{array}$} & Private & 3.711149*** & $\begin{array}{c}- \\
4.274890 * * *\end{array}$ & $\begin{array}{c}- \\
\\
4.278765^{* * *}\end{array}$ \\
\hline & Public & -1.677118 & $\begin{array}{c}- \\
16.11016^{* * *}\end{array}$ & $\begin{array}{c}- \\
16.16882^{* * *}\end{array}$ \\
\hline
\end{tabular}

\begin{tabular}{|c|c|c|c|c|}
\hline Panel & Total & $\begin{array}{c}- \\
2.637025^{* * *}\end{array}$ & $\begin{array}{c}- \\
14.74665^{* * *}\end{array}$ & $\begin{array}{c}- \\
11.91655^{* * *}\end{array}$ \\
\hline \multirow{3}{*}{$\begin{array}{c}\text { Lower } \\
\text { Middle - } \\
\text { Income } \\
\text { Country } \\
\text { Panel }\end{array}$} & Private & $\begin{array}{c}- \\
5.439227 * * *\end{array}$ & $-3.324080 * *$ & $-3.2382 *$ \\
\hline & Public & $\begin{array}{c}- \\
13.94380 * * *\end{array}$ & -1.256550 & -1.391627 \\
\hline & Total & $\begin{array}{c}- \\
12.74557 * * *\end{array}$ & -2.102899 & -2.176530 \\
\hline \multirow{3}{*}{$\begin{array}{c}\text { Low } \\
\text { Income } \\
\text { Country } \\
\text { Panel }\end{array}$} & Private & $\begin{array}{c}- \\
4.284956^{* * *}\end{array}$ & $\begin{array}{c}- \\
5.208941^{* * *}\end{array}$ & $\begin{array}{c}- \\
4.934337^{* * *}\end{array}$ \\
\hline & Public & $\begin{array}{c}- \\
3.633259 * * *\end{array}$ & $-2.7849 *$ & -2.945812 \\
\hline & Total & $\begin{array}{c}- \\
4.162593 * * *\end{array}$ & $\begin{array}{c}- \\
4.828667 * * *\end{array}$ & $\begin{array}{c}- \\
4.268870^{* * *}\end{array}$ \\
\hline
\end{tabular}

Note: $*, * *$, and $* * *$ remarks rejection of $\mathrm{H} 0$ at $\% 10, \% 5,1 \%$ significance level, respectively.

Next, we implement Kapetanios et al. (2003) panel stationarity approach which accommodates ESTAR type of nonlinearity in the data generating procedure. From the results in Table $\mathbf{3}$, it is clearly can be stated that public health care spending is non-stationary for high and upper-middleincome countries whereas private health care consumption is non-stationary only for high-income country groups. The possible reason for it may be more efficiently and rapidly integration of technological progress into the health care sector in the countries with the higher income level.

As Stephan (1934) argues, social data in consequence of their very social character, persons, groups and their features are intersectional and not unconnected. Moreover, expanding economic and financial integration across the countries also causes strong interdependencies between countries in the recent decades leading to cross-section dependence among the elements of the panel. So, since results obtained from the estimated regression model may involve biased inferences, we employ Pesaran (2004) to explore whether series crosssectionally depended or not.

Table 4. Panel Cross-Section Dependence Test.

\begin{tabular}{|c|c|c|}
\hline \multirow{4}{*}{$\begin{array}{c}\text { Health Care Expenditure } \\
\text { HE }\end{array}$} & CSD \\
\hline \multirow{2}{*}{$\begin{array}{c}\text { Panel } \\
\text { Hpper Middle-Income } \\
\text { Country Panel }\end{array}$} & Private & -1.4307 \\
\cline { 2 - 3 } & Public & -2.4172 \\
\cline { 2 - 3 } & Total & 119.591 \\
\cline { 2 - 3 } & Private & 3.7625 \\
\hline \multirow{2}{*}{$\begin{array}{c}\text { Lower Middle-Income } \\
\text { Country Panel }\end{array}$} & Public & 8.0538 \\
\cline { 2 - 3 } & Total & 2.0742 \\
\cline { 2 - 3 } & Private & 3.3605 \\
\hline \multirow{2}{*}{$\begin{array}{c}\text { Public } \\
\text { Total }\end{array}$} & 0.6725 \\
\hline
\end{tabular}




\begin{tabular}{|c|c|c|}
\hline \multirow{4}{*}{ Low Income Country Panel } & Private & -0.4042 \\
\cline { 2 - 3 } & Public & -2.8717 \\
\cline { 2 - 3 } & Total & -2.7008 \\
\hline
\end{tabular}

Note: ** remarks rejection of $\mathrm{H} 0$ at $\% 5$ significance level.

According to the results in Table 4, cross-sectional independence between the series may be ignored only for total health care expenditure series in the lower-middle-income country group. This evidence requires implementing secondgeneration panel stationarity analyses as Pesaran (2007) which considers possible cross-sectional dependence among the variables during the investigation of stationarity properties. From the results obtained, as presented in Table 5, the null hypothesis of non-stationarity may be ignored for total health care expenditure series in the reference country group, implying that health consumption series are stationary when we consider linear data generating process involving crosssectional dependence.

Table 5. Panel Linear Unit Root Test Results.

\begin{tabular}{|c|c|c|}
\hline \multirow{2}{*}{$\begin{array}{c}\text { Lower-Middle- Income Country } \\
\text { Panel }\end{array}$} & $\begin{array}{c}\text { Health Care Expenditure } \\
\text { HE }\end{array}$ & CSD \\
\cline { 2 - 3 } & Total & - \\
& & $2.1249 * *$ \\
\hline
\end{tabular}

Note: ** remarks rejection of $\mathrm{H} 0$ at $\% 5$ significance level.

These findings encouraged us finally to employ a nonlinear heterogeneous panel unit root test, suggested by Cerrato et al. (2011). Taking into account the results represented in Table 6, the null hypothesis which states that observed series follow non-stationary processes against the alternative hypothesis can be rejected for series in the lower-middleincome country group.

Table 6. Panel Nonlinear Unit Root Test Results.

\begin{tabular}{|c|c|c|}
\hline \multirow{2}{*}{$\begin{array}{c}\text { Lower Middle-Income Country } \\
\text { Panel }\end{array}$} & $\begin{array}{c}\text { Health Care Expenditure } \\
\text { HE }\end{array}$ & NLPADF \\
\cline { 2 - 3 } & Total & - \\
& & $2.1458 * *$ \\
\hline
\end{tabular}

Note: ** remarks rejection of $\mathrm{H} 0$ at $\% 5$ significance level.

Based on the last two tables, when cross-section dependence is taken into account, total health care expenditures series also in lower-middle-income countries appear to be either linear or non-linear stationary.

\section{CONCLUDING REMARKS}

Incontrovertible effect of health care spending on economic growth and development process makes health care policy implementations critical for all economies independently income level of countries. The fact that health care variables may follow a non-linear pattern and it may be ignored in the previous studies encourages us to revise empirical evidence of unit root for health care spending series generated both linearly and non-linearly as well as to test whether the sto- chastic features of total health expenditure varies if it disaggregated into private and public consumption. For this purpose, we employ a data set for 188 countries over the period 1995-2014 which are categorized into four groups based on the World Bank income categories.

The findings obtained from linear unit root tests suggest that total health care expenditure series are non-stationary in the level for all country groups, whereas disaggregating these series as public and private does not demonstrate strong evidence of non-stationarity. Moreover, allowing for crosssection dependency among the series and nonlinearity in the estimation procedure leads to more frequent rejection of the null hypothesis of unit root, as well as fading of differences among public and private series for each country group. It may be explained by the fact that health care consumption is crucial for the population irrespective of the countries' income level and people demand stability in health care policies. Additionally, policymakers' purposes of getting the majority of votes in upcoming elections may motivate them to keep the public sector's technological advancement in line with private sectors leading to public health care spending series being stationary.

Furthermore, since health care spending does not follow a stochastic trend, then any shocks on health care consumption will have temporal effects and health care spending may recur to its initial equilibrium level as time progresses. We may conclude that it may be better for the policymakers to take non-interventionist or more liberal actions in the health care market process to eliminate the results of particular cyclical fluctuations.

\section{CONFLICT OF INTEREST STATEMENT}

The authors declare that they have no conflict of interest.

\section{REFERENCES}

Baltagi, B.H., Moscone, F. (2010). Health care expenditure and income in the OECD reconsidered: Evidence from panel data. Economic Modelling, 27(4), 804-811.

Blomqvist, Å.G., Carter, R.A.L. (1997). Is health care really a luxury? Journal of Health Economics, 16(2), 207-229.

Bloom, D.E., Canning, D. (2000). The Health and Wealth of Nations. Science's Compass, Policy Forum: Public Health, 287: 1207-1209.

Breitung, J. (2001). The local power of some unit root tests for panel data. Baltagi, B., Fomby, T. and Carter Hill, R. (Ed.) Nonstationary Panels, Panel Cointegration, and Dynamic Panels (Advances in Econometrics, Vol. 15), Emerald Group Publishing Limited,161-177.

Breusch, T.S., Pagan, A.R. (1980). The Lagrange multiplier test and its applications to Model Specification Tests in econometrics. Review of Economic Studies, 47(1), 239-53.

Carrion-i-Silvestre, J.L. (2005). Health care expenditure and GDP: Are they broken stationary? Journal of Health Economics, 24, 839-854.

Cerrato, M., De Peretti, C., Larsson, R., Sarantis, N. (2011). A nonlinear panel unit root test under cross section dependence. Sire Discussion Paper. SIRE-DP-2011-30.

Choi, I. (2001). Unit root tests for panel data. Journal of International Money and Banking, 20, 249-272.

DeHoyos, R. E., Sarafidis, V. (2006). Testing for cross-sectional dependence in panel data models. Stata Journal, 6, 482-496.

Dickey, D.A., Fuller, W.A. (1979). Distribution of the estimators for autoregressive time series with a unit root. Journal of the American Statistical Association, 427-431.

Dreger, C., Reimers, H.E. (2005). Health care expenditures in OECD countries: a panel unit root and co-integration analysis. IZA Discussion Paper No. 1469. 
Gerdtham, U.G., Søgaard, J., Andersson, F., Jönsson, B. (1992). An econometric analysis of health care expenditure: A cross-section study of the OECD countries. Journal of Health Economics, 11(1), 63-84.

Gerdtham, U.G., Lothgren, M. (2002). New panel results on co-integration of international health expenditure and GDP. Applied Economics, 34(13), 1679-1686.

Getzen, T.E., Poullier, J. (1992). International health spending forecasts: concepts and evaluation. Social Science and Medicine, 34, 1057 1068.

Granger, C. W. J., T. Terasvirta. (1993). Modelling nonlinear economic relationships. Oxford: Oxford University Press.

Grossman, M. (1972). On the concept of health capital and the demand for health. Journal of Political Economy, 80(2), 223-255.

Hadri, K. (2000). Testing for stationarity in heterogeneous panel data. Econometrics Journal, 3, 148-161.

Hansen, P., King, A. (1996). The determinants of health care expenditure: a co-integration approach. Journal of Health Economics, 15(1), 127137.

Hasanov, M., Telatar, E. (2011). A re-examination of stationarity of energy consumption: Evidence from new unit root tests". Energy Policy, 39(12), 7726-7738.

Hendry, D.F., Juselius, K. (2000). Explaining co-integration analysis: part I. Energy Journal, 21, 1-42.

Hitiris, T., Posnett, J. (1992). The determinants and effects of health expenditure in developed countries. Journal of Health Economics, 11(2), 173-181.

Im, K.S., Pesaran, H.M., Shin, Y. (2003). Testing for unit roots in heterogeneous panels. Journal of Econometrics, 115, 53-74.

Jewell, T., Lee, J., Tieslau, M., Strazicich, M.C. (2003). Stationarity of heath expenditures and GDP: evidence from panel unit root tests with heterogeneous structural breaks. Journal of Health Economics, $22,313-323$

Kapetanios, G., Shin, Y., Snell, A. (2003). Testing for a unit root in the nonlinear STAR framework. Journal of econometrics, 112, 359379.

Ke, X., Saksena, P., Holly, A., (2011). The determinants of health expenditure: a country-level panel data analysis. A Working Paper of the Results for Development Institute (R4D), Geneva.

Kim, H., Kim, J. (2018). London calling: Nonlinear mean reversion across national stock markets. The North American Journal of Economics and Finance, 44, 265-277.

Kleiman, E. (1974). The Determinants of National Outlay on Health. In: Perlman M. (eds). The Economics of Health and Medical Care. International Economic Association Series. Palgrave Macmillan, London.

Kouassi, E., Akinkugbe, O., Kutlo, N. O., \& Brou, J. M. B. (2018). Health expenditure and growth dynamics in the SADC region: Evidence from non-stationary panel data with cross section dependence and unobserved heterogeneity. International Journal of Health Economics and Management, 18, 47-66.

Lago-Peñas, S., Cantarero-Prieto, D., \& Blázquez-Fernández, C. (2013). On the relationship between GDP and health care expenditure: A new look. Economic Modelling, 32, 124-129.

Lee, H., Oh, DY., Meng, M. (2019). Stationarity and cointegration of health care expenditure and GDP: evidence from tests with smooth structural shifts. Empirical Economics, 57, 631-652.

Levin, A.C., Lin, F., Chu, C.S.J. (2002). Unit root tests in panel data: Asymptotic and finite sample properties. Journal of Econometrics, $108,1-24$.

Luukkonen, R., Saikkonen, P., TerSasvirta, T. (1988). Testing linearity against smooth transition autoregressive models. Biometrika, 75, 491-499.
Maddala, G. S., Wu, S. (1999). A comparative study of unit root tests with panel data and a new simple test. Oxford Bulletin of Economics and Statistics, 61(s1): 631-652.

McCanne, D. (2010). Health Care Systems-Four Basic Models; Physicians for a National Health Program.

Mc-Coskey, S.K., Selden, T.M. (1998). Health care expenditure and GDP: panel data unit root test results. Journal of Health Economics, 17 369-376.

Mehrara, M., Fazaeli, A.A., Fazaeli, A.A., Fazaeli, A.R. (2012). The Relationship between Health Expenditures and Economic Growth in Middle East \& North Africa (MENA) Countries. International Journal of Business Management \& Economic Research 3(1), 425428 .

Mohamed, C. (2009). Health care expenditure and GDP: An international panel smooth transition approach. International Journal of Economics, 4(1).

Murthy, V., Okunade, A. (2009). The core determinants of health expenditure in the African context: Some econometric evidence for policy. Health Policy, 91(1), 57-62.

Musgrove, P., Zeramdini, R., Carrin, G. (2002). Basic patterns in national health expenditure. Bulletin of the World Health Organization, 80(2), 134-142.

Newhouse, J.P. (1977). Medical-care expenditure: a cross-national survey. The Journal of Human Resources, 12(1), 115-125.

Okunade, A.A., Karakus, M.C. (2001). Unit root and co-integration tests: time series versus panel estimates for international health expenditure models. Applied Economics, 33(9), 1131-1137.

Pattnayak, S.S., Chadha, A. (2016) Is health care a luxury? The debate revisited with new evidence from emerging economies, Applied Economics, 48(34), 3195-3207.

Pesaran, M.H. (2004). General Diagnostic Tests for Cross Section Dependence in Panels. Cambridge Working Papers in Economics No:435.

Pesaran, M.H. (2007). A simple panel unit root test in the presence of crosssection dependence. Journal of Applied Econometrics, 22(2), 265312.

Phillips, P.C.B. (1986). Understanding spurious regressions in econometrics. Journal of Econometrics, 33(3), 311-340.

Phillips, P. C.B., Sul, D. (2003). Dynamic panel estimation and homogeneity testing under cross section dependence. The Econometrics Journal, 6(1), 217-259.

Poullier J.P, Hernandez P, Kawabata K, Savedoff, D.W. (2002). Patterns of global health expenditures: results for 191 countries. WHO Discussion Paper. No51.

Rana, R.H., Alam, K., Gow, J. (2020). Health expenditure and gross domestic product: causality analysis by income level. International Journal of Health Economics and Management, 20, 55-77.

Rodríguez, A.F., Nieves Valdés, M. (2019). Health care expenditures and GDP in Latin American and OECD countries: a comparison using a panel co-integration approach. International Journal of Health Economics Management, 19(2), 115-153.

Roberts, J. (1999). Sensitivity of elasticity estimates for OECD health care spending: analysis of a dynamic heterogeneous data field. Health Economics, 8(5), 459-472.

Stephan, F.F. (1934). Sampling errors and interpretations of social data ordered in time and space. Journal of the American Statistical Association, 29, 165-166.

Taylor, M.P., Peel, D.A., Sarno, L. (2001). Nonlinear mean-reversion in real exchange rates: toward a solution to the purchasing power parity puzzles. International Economic Review, 42, 1015-1042. 